\title{
Mechanical and Fracture Parameters of Ultra-High Performance Fiber Reinforcement Concrete Cured via Steam and Water: Optimization of Binder Content
}

\author{
Avan Ahmed Mala ${ }^{1}\left(\mathbb{D}\right.$, Aryan Far H. Sherwani ${ }^{2}(\mathbb{D})$, Khaleel H. Younis ${ }^{3,4} \mathbb{( D}$, Rabar H. Faraj $^{5, *(\mathbb{D})}$ and \\ Amir Mosavi $6,7,8, *$ (D)
}

1 Department of Civil Engineering, Gaziantep University, Gaziantep 27400, Turkey; avan.mala1@gmail.com

2 Department of Civil Engineering, Faculty of Engineering, Soran University, Soran 44008, Kurdistan Region, Iraq; aryanfar.abd@soran.edu.iq

3 Road Construction Department, Erbil Technology College, Erbil Polytechnic University, Erbil 44001, Kurdistan Region, Iraq; khaleel.younis@epu.edu.iq

4 Civil Engineering Department, Tishk International University, Erbil 44001, Kurdistan Region, Iraq

5 Civil Engineering Department, University of Halabja, Halabja 46006, Kurdistan Region, Iraq

6 Faculty of Civil Engineering, Technische Universität Dresden, 01069 Dresden, Germany

7 Institute of Structural Mechanics, Bauhaus Universität-Weimar, 99423 Weimar, Germany

8 John von Neumann Faculty of Informatics, Obuda University, 1034 Budapest, Hungary

* Correspondence: rabar.faraj@uoh.edu.iq (R.H.F.); amir.mosavi@mailbox.tu-dresden.de (A.M.)

check for

updates

Citation: Mala, A.A.; Sherwani, A.F.H.; Younis, K.H.; Faraj, R.H.; Mosavi, A. Mechanical and Fracture Parameters of Ultra-High

Performance Fiber Reinforcement Concrete Cured via Steam and Water: Optimization of Binder Content. Materials 2021, 14, 2016. https:// doi.org/10.3390/ma14082016

Academic Editor: Bora Gencturk

Received: 21 March 2021

Accepted: 13 April 2021

Published: 16 April 2021

Publisher's Note: MDPI stays neutral with regard to jurisdictional claims in published maps and institutional affiliations.

Copyright: (c) 2021 by the authors. Licensee MDPI, Basel, Switzerland. This article is an open access article distributed under the terms and conditions of the Creative Commons Attribution (CC BY) license (https:/ / creativecommons.org/licenses/by/ $4.0 /)$.

\begin{abstract}
An investigational study is conducted to examine the effects of different amounts of binders and curing methods on the mechanical behavior and ductility of Ultra-High Performance Fiber Reinforced Concretes (UHPFRCs) that contain 2\% of Micro Steel Fiber (MSF). The aim is to find an optimum binder content for the UHPFRC mixes. The same water-to-binder ratio $(\mathrm{w} / \mathrm{b})$ of 0.12 was used for both water curing (WC) and steam curing (SC). Based on the curing methods, two series of eight mixes of UHPFRCs containing different binder contents ranging from 850 to $1200 \mathrm{~kg} / \mathrm{m}^{3}$ with an increment of $50 \mathrm{~kg} / \mathrm{m}^{3}$ were produced. Mechanical properties such as compressive strength, splitting tensile strength, static elastic module, flexural tensile strength and the ductility behavior were investigated. This study revealed that the mixture of $1150 \mathrm{~kg} / \mathrm{m}^{3}$ binder content exhibited the highest values of the experimental results such as a compressive strength greater than $190 \mathrm{MPa}$, a splitting tensile strength greater than $12.5 \mathrm{MPa}$, and a modulus of elasticity higher than $45 \mathrm{GPa}$. The results also show that all of the improvements began to slightly decrease at $1200 \mathrm{~kg} / \mathrm{m}^{3}$ of the binder content. On the other hand, it was concluded that SC resulted in higher mechanical performance and ductility behavior than WC.
\end{abstract}

Keywords: mechanical properties; fracture parameters; micro steel fibers; binder content; steam curing; water curing; ultra-high performance fiber reinforced concrete (UHPFRC); silica fume; fracture mechanics; materials design

\section{Introduction}

Developing in concrete materials can be grouped into three phases. The first phase is conventional concrete that offers normal strength. The second one is high-strength concrete (HSC), which provides higher strength and is a harder material than the former one. The third phase is HSC, which can be distinct with its high compressive strength of almost $70 \mathrm{MPa}$, flexural tensile strength of nearly $10 \mathrm{MPa}$, and the modulus of elasticity ranging between 14 and $42 \mathrm{GPa}$. Nowadays, given the enhancements on the scale of the microscope, reactive powder concrete (RPC) technology is considered a patent in the area of concrete technology known as ultra-high performance concrete [1]. The concept of RPC was first developed by Richard and Cheyrezy [2] Currently, it is considered as Ultra-High Performance Concrete Composite (UHPC). UHPC is considered one of the 
latest developments in the technology of concrete, and improving many concrete deficiencies [3]. UHPC can be distinct with normal concrete and high performance concrete with its microscale properties of the particle size and the constituent materials [4]. It has been used in many major applications including coupling beams in tall buildings, precast elements, infrastructure repair, and vast facilities such as nuclear waste storage tanks $[5,6]$. Manufacturing UHPC requires ultra-content of cement and silica fume (SF) as the total binder content for improving the workability, fine grained quartz sand ranged between 150 and $400 \mu \mathrm{m}$ to reduce the thickness of the paste, low water/binder $(\mathrm{w} / \mathrm{b})$ of $<0.2$, and a special type of superplasticizer (SP) to achieve a workable concrete [7-9]. We examined UHPC with a w/b of 0.24 , binder amount of $657 \mathrm{~kg} / \mathrm{m}^{3}$ and a Quarry dust content of $1050 \mathrm{~kg} / \mathrm{m}^{3}$ using a particle size ranging between $150 \mu \mathrm{m}$ and $1.18 \mathrm{~mm}$ [10]. To attain a workable concrete, superplasticizer was used. The highest rate of compressive strength attained was $122.4 \mathrm{MPa}$. The main lack of plain UHPC is low in tensile strength versus the high values of compressive strength [11].

When fibers are incorporated, UHPC is called Ultra-High Performance Concrete Reinforced with Fibers (UHPFRC) [12]. Irrespective of its size, type, and shape, the fibers have a key role in enhancing the confrontation of plain UHPC to cracking, ductility, and toughness properties. In UHPFRC, fibers have the potential to promote energy absorption, strain hardening under tension, and to avoid sudden failure [13-16]. Micro fibers from different resources, including steel, glass, and carbon, are usually employed to produce UHPFRC [17]. For the determination of fracture energy, inverse analysis can be utilized to classify it, but this needs to utilize a particular test program and numerical methods [18]. UHPFRC is usually characterized with ultimate strength, superior fracture parameter, and an enhanced durability if proper manufacturing techniques and curing conditions (water, steam or autoclave curing) are adopted. Steam curing for UHPC is very effective not only because of enhancing the hydration of large amounts of un-hydrated cement inside UHPCs due to large quantities of binder, but it also helps in controlling the moisture movement from and into the concrete [19]. Therefore, researchers preferred steam over water curing for the production of UHPFRCs and superior results were obtained [20,21]. For instance, steam curing of concrete at atmospheric pressure results in a considerable increment in the strength development rate. This method is mainly used for prefabricated concrete parts such as pipes, and prestressed elements; nonetheless, it can also be utilized for closed inlet in situ constructions. In the manufacturing of precast concrete elements, steam curing enables higher production through faster turnover mold and formwork, shorter curing times before shipping, and less product damage during transporting. The pozzolanic reaction, which is thermally activated due to the high curing temperature of steam curing leads to the growth of C-S-H and decrease in calcium hydroxide [22].

The influence of the curing temperature on the properties of cement mortars and concretes was the focus of some studies. It has been largely clarified that curing at a high temperature immediately after casting provides the growth of mechanical characteristics in the initial ages, then adversely affects strength in the final ages. Mouret et al. [23] stated that at 28 days, $10 \%$ reduction in compressive strength was detected when the concrete cured at $35{ }^{\circ} \mathrm{C}$ related to the concrete cured at $20^{\circ} \mathrm{C}$. Furthermore, with increasing the curing regime from 20 and $50{ }^{\circ} \mathrm{C}$, the strength decreased by up to $28 \%$. This drop down of strength in later age refers to the sudden hydration rate in early ages due to the higher temperature, which delays the consequent hydration and forms a non-uniform distribution of the hydration products [24]. Ho et al. [25] explored the possible benefits of steam curing of concrete with the combination of fly ash, slag and silica fume. It was obtained that mixtures with silica fume (SF) provided a good strength performance and low sorptivity in early ages. Valikhani et al. [26] stated that UHPC at 28 days cured in ambient condition showed a compressive strength of $126 \mathrm{MPa}$ and a tensile strength of $6.5 \mathrm{MPa}$. Further studies are required to implement different curing methods of UHPC to investigate the development strength at different ages. For this purpose, in the current study, water curing 
(WC) and steam curing (SC) were applied to produce UHPC based on blended binders such as cement and SF.

The benefits of using silica fume (SF) in concrete mixes include: improving compressive strength, bond strength, and wear resistance; additionally, the resistance against permeability and the corrosion resistance of the embedded are improved [27]. In cementitious matrix, SF is the most widely used amorphous silica. The average particle size of SF is approximately one-tenth that of cement. SF has been utilized in the range of $10-25 \%$ by weight of cement since the 1950s due to its Pozzolans and filler properties that make the concrete denser [8]. SF and calcium hydroxide react together to make more C-S-H gel, accordingly improving the final strength [9]. Furthermore, some investigators such as Dunster [10] stated that the contributions of SF and concrete components could minimize cement consumption, which has become sustainable with regards to economic and environmental development.

Various studies have been implemented on the effects of different parameters, including fibers, mineral admixtures and curing condition, on the behavior of UHPFRC. For instance, the effects of various types of fibers on the mechanical performance and ductility behavior cured in water have been studied by researchers [28,29]. For this purpose, a w/b of 0.195 and different types of fiber content ranging between 0.25 and $2 \%$ fiber volume fraction were used. It was concluded that the maximum compressive strength was $180 \mathrm{MPa}$ for the micro steel fibers (MSF) and that, for flexural strength, the hooked steel fibers were more effective [30]. Moreover, the effects of nano-silica and micro-silica on the mechanical properties for the $0.2 \mathrm{w} / \mathrm{b}$ of UHPC were also investigated by Gesoglu et al. [31]. It was also detected that the binary usage of nano-silica and micro-silica provide superior performance than the individual utilization. Maleka et al. [20] investigates UHPFRC by using blended cement and SF. The content of cement that was chosen in this research was 700, 750 and $800 \mathrm{~kg} / \mathrm{m}^{3}$ and SF content of 0,15 , and $30 \%$ of cement content. The study has recommended the inclusion of the SF of up to $30 \%$ of cement content. Also, Yazic1 et al. [32] studied the mechanical properties under different curing regimes containing mineral admixtures. They revealed that the steam and autoclave curing looked like very effective ways to improve the strengths of UHPCs. However, there is very limited research on investigating the optimum content of binder and its effect on the mechanical and fracture parameters of UHPFRC cured via different methods

As a result of reviewing the available literature, the question on how to find the optimum balance between the binder content and aggregate volume to improve the performance of UHPC has become our main concern to find an answer for. Therefore, an experimental program is prepared by taking different volumes of binder ranging between 850 and $1200 \mathrm{~kg} / \mathrm{m}^{3}$ with an augmentation of $50 \mathrm{~kg} / \mathrm{m}^{3}$ for investigating strength and fracture parameters of UHPFRC. Moreover, the effect of curing methods (WC and ST) on the UHPFRCs were taken into account. Furthermore, parameters such as flowability of concrete, $\mathrm{w} / \mathrm{b}$ ratio, SF and MSF content were kept constant unlike the binder content and curing methods (steam curing and water curing) which were varied for optimization purposes of the results of compressive strength, splitting strength, modulus of elasticity, flexural strength, load-displacement curves, fracture energy, and characteristic length.

\section{Experimental Study}

\subsection{Materials}

To implement the experimental study, Portland cement type CEM I $42.5 \mathrm{R}$ and supplementary cementitious materials such as Silica Fume (SF) were utilized as additional cementitious materials (see Table 1). The cementitious materials were provided by local companies from the city of Gaziantep, Turkey. Commercial quartz sand as fine aggregate (specific gravity of 2.65) used with three dissimilar size portions having a particle size in the range of $0-0.4,0.6-1.2$, and $1.2-2.5 \mathrm{~mm}$ was utilized as an alternative to the coarse aggregate. Since it is detected that with decreasing the $\mathrm{w} / \mathrm{b}$ the strength of hardened cement based-materials will increase with decreasing porosity $[33,34]$, the water-to-binder 
ratio $(\mathrm{w} / \mathrm{b})$ for UHPFRC is taken as 0.12 in this study. Type $\mathrm{F}$ polycarboxylate-based superplasticizer was used to achieve the workability [35]. To provide fiber reinforcement, micro steel fibers (MSF) were used with $2 \%$ volume fraction as shown. Table 2 shows the properties and the aspect ratios of the MSF.

Table 1. Physical and chemical characteristics of Portland cement and silica fume.

\begin{tabular}{ccc}
\hline Constituent (\%) & PC & SF \\
\hline $\mathrm{CaO}$ & 57.87 & 0.45 \\
$\mathrm{SiO}_{2}$ & 17.99 & 90.36 \\
$\mathrm{Al}_{2} \mathrm{O}_{3}$ & 3.88 & 0.71 \\
$\mathrm{Fe}_{2} \mathrm{O}_{3}$ & 3.36 & 1.31 \\
$\mathrm{MgO}_{\mathrm{SO}}$ & 1.49 & - \\
$\mathrm{K}_{2} \mathrm{O}$ & 2.47 & 0.41 \\
$\mathrm{Na}_{2} \mathrm{O}$ & - & 1.52 \\
$\mathrm{Cl}$ & - & 0.45 \\
Loss of Ignition & 0.005 & - \\
Insoluble Residue & 3.37 & 3.11 \\
Free CaO & 0.34 & - \\
Specific surface (m $\left.{ }^{2} / \mathrm{kg}\right)$ & 2.18 & - \\
Specific gravity & $394 \mathrm{a}$ & $21,080^{\mathrm{b}}$ \\
\hline
\end{tabular}

${ }^{a}$ Blaine specific surface area. ${ }^{b}$ BET specific surface area.

Table 2. Aspect ratio, physical and mechanical properties of MSF.

\begin{tabular}{cccccc}
\hline Type & $\begin{array}{c}\text { Length (L) } \\
(\mathbf{m m})\end{array}$ & $\begin{array}{c}\text { Diameter }(\mathbf{d}) \\
(\mathbf{m m})\end{array}$ & $\begin{array}{c}\text { Aspect Ratio } \\
(\mathbf{L} / \mathbf{d})\end{array}$ & $\begin{array}{c}\text { Density } \\
\left(\mathbf{g} / \mathbf{c m}^{\mathbf{3}}\right)\end{array}$ & $\begin{array}{c}\text { Tensile Strength } \\
\left(\mathbf{N} / \mathbf{m m}^{\mathbf{2}}\right)\end{array}$ \\
\hline MSF & 6 & 0.16 & 37.5 & 7.17 & 2250 \\
\hline
\end{tabular}

\subsection{Mixing and Casting}

The UHPFRC mix ingredients examined in the current research work are considered with high binder content and $2 \%$ of MSFs, eliminate the coarser aggregates, and a very low $\mathrm{w} / \mathrm{b}$ ratio like other studies [36-39]. The mixing proportions in this research work comprise two groups, as illustrated in Table 3, depending on curing type (water curing and steam curing) with the same $\mathrm{w} / \mathrm{b}$ of 0.12 . For each mix group, eight mixes of different binder content were casted ranging from 850 to $1200 \mathrm{~kg} / \mathrm{m}^{3}$ by $50 \mathrm{~kg} / \mathrm{m}^{3}$ increments as a total cementitious material. The silica fume (SF) was kept constant as $15 \%$ of the total weight of the binder for the two groups. In order to adjust the workability of concrete, superplasticizer was utilized in a different rate. The mixes were labeled according to the binder content and curing types. For instance, $950 \mathrm{SC}$ specifies the mix holding $950 \mathrm{~kg} / \mathrm{m}^{3}$ of binder and cured by steam.

The UHPC mixes were produced by a high-speed mixer, the maximum rate of rotating of which reaches up to $470 \mathrm{rpm}$. The dry ingredients were mixed at $100 \mathrm{rpm}$ for the first $3 \mathrm{~min}$. After the water was added, the batch was mixed at a speed of $100 \mathrm{rpm}$ for an additional $5 \mathrm{~min}$. SP was then fed to the mixed batch and continued at maximum speed for another $5 \mathrm{~min}$. Next, 2\% of MSF was added at a lower speed (100 rpm) for $2 \mathrm{~min}$, and the mixed materials resumed for the last $2 \mathrm{~min}$ at a maximum speed. Finally, the fresh UHPFRCs were then placed in the molds of different sizes as follows: 3 cubes $50-\mathrm{mm}^{3}$, 3 cubes of $70 \mathrm{~mm}^{3}, 3$ cubes of $150 \mathrm{~mm}^{3}$, and 3 prisms of $70 \mathrm{~mm} \times 70 \mathrm{~mm} \times 280 \mathrm{~mm}$ in dimensions for determining mechanical and fracture parameters of the UHPFRCs. Later, the specimens were compacted by means of vibrating table and then wrapped with a nylon sheet and left in the molds for about $24 \mathrm{~h}$ at ambient temperature for the first group. Then, after the specimens were demolded, the first group stored in water that cured at $20^{\circ} \mathrm{C}$ until testing date and samples for the second group were subjected to steam curing at $90^{\circ} \mathrm{C}$ with 
a relative humidity of $95 \%$ and the cycle took about $48 \mathrm{~h}$ and later put in water at $20{ }^{\circ} \mathrm{C}$ up to the testing day.

Table 3. Mixing proportions of UHPFRC in $\mathrm{kg} / \mathrm{m}^{3}$.

\begin{tabular}{|c|c|c|c|c|c|c|c|c|}
\hline Mix Group & Code & Binder Content & $\mathbf{w} / \mathbf{b}$ & Cement & SF & Water & MSF (\%) & Aggregate \\
\hline \multirow{8}{*}{$\begin{array}{l}\text { Water-Cured } \\
\text { Group } \\
\text { (8 mixes) }\end{array}$} & $850 W C$ & 850 & 0.12 & 722.5 & 127.5 & 102 & 2 & 1365.8 \\
\hline & 900WC & 900 & 0.12 & 765 & 135 & 108 & 2 & 1312.6 \\
\hline & 950WC & 950 & 0.12 & 807.5 & 142.5 & 114 & 2 & 1254.4 \\
\hline & 1000WC & 1000 & 0.12 & 850 & 150 & 120 & 2 & 1199.9 \\
\hline & 1050WC & 1050 & 0.12 & 892.5 & 157.5 & 126 & 2 & 1145.9 \\
\hline & 1100WC & 1100 & 0.12 & 935 & 165 & 132 & 2 & 1092.5 \\
\hline & 1150WC & 1150 & 0.12 & 977.5 & 172.5 & 138 & 2 & 1036.6 \\
\hline & 1200WC & 1200 & 0.12 & 1020 & 180 & 144 & 2 & 972.9 \\
\hline \multirow{8}{*}{$\begin{array}{l}\text { Steam-Cured } \\
\text { Group } \\
\text { (8 mixes) }\end{array}$} & $850 S C$ & 850 & 0.12 & 722.5 & 127.5 & 102 & 2 & 1365.8 \\
\hline & 900SC & 900 & 0.12 & 765 & 135 & 108 & 2 & 1312.6 \\
\hline & 950SC & 950 & 0.12 & 807.5 & 142.5 & 114 & 2 & 1254.4 \\
\hline & 1000SC & 1000 & 0.12 & 850 & 150 & 120 & 2 & 1199.9 \\
\hline & 1050SC & 1050 & 0.12 & 892.5 & 157.5 & 126 & 2 & 1145.9 \\
\hline & 1100SC & 1100 & 0.12 & 935 & 165 & 132 & 2 & 1092.5 \\
\hline & 1150SC & 1150 & 0.12 & 977.5 & 172.5 & 138 & 2 & 1036.6 \\
\hline & 1200SC & 1200 & 0.12 & 1020 & 180 & 144 & 2 & 972.9 \\
\hline
\end{tabular}

\subsection{Curing Condition}

Two curing methods were implemented in this study for the same series, including water curing (WC) and steam curing (SC). The group of WC-UHPFRC was demolded $24 \mathrm{~h}$ after the mixing date and then put in a water tank at $20^{\circ} \mathrm{C}$ until the testing age. Conversely, in the condition of SC, UHPFRC samples were put into the camber with the molds and subjected to steam in a fresh state. In the current study, the SC cycle had a total duration of $48 \mathrm{~h}$, accounting for two hours of preheating, three hours of increasing the rate of heating to get the maximum value of $90^{\circ} \mathrm{C}$, and the temperature was constant for $41 \mathrm{~h}$ and lastly the chamber was cooled for two hours. The relative humidity in the SC chamber was about $95 \%$. Consequently, the hardened samples were demolded and kept in water at $20^{\circ} \mathrm{C}$ up to the testing day.

\subsection{Testing Methods}

Figure 1 shows the detailed testing process that was conducted in this study. Before the curing process, the mixtures of UHPFRC have been tested for workability, then casted and subjected to curing until the testing date. To implement the compression test, cubic molds of $50 \mathrm{~mm}$ were cast and tested at 7 and 28 days following the ASTM C39 [40]. For each reading, an average of three samples was taken. A splitting test was done on the cube of $70 \mathrm{~mm}$ at an age of 28 days with respect to ASTM C496 [41]. Meanwhile, a cubic sample of $150 \mathrm{~mm}$ was tested at 28 days to measure the modulus of elasticity as specified in ASTM C469 [42]. The specimens were 3 times loaded and unloaded, and the subject load was equal to $40 \%$ of the maximum load that could be carried in compression state. The modulus of elasticity for each cube is the average of the second and third set of readings with eliminating the first one. 


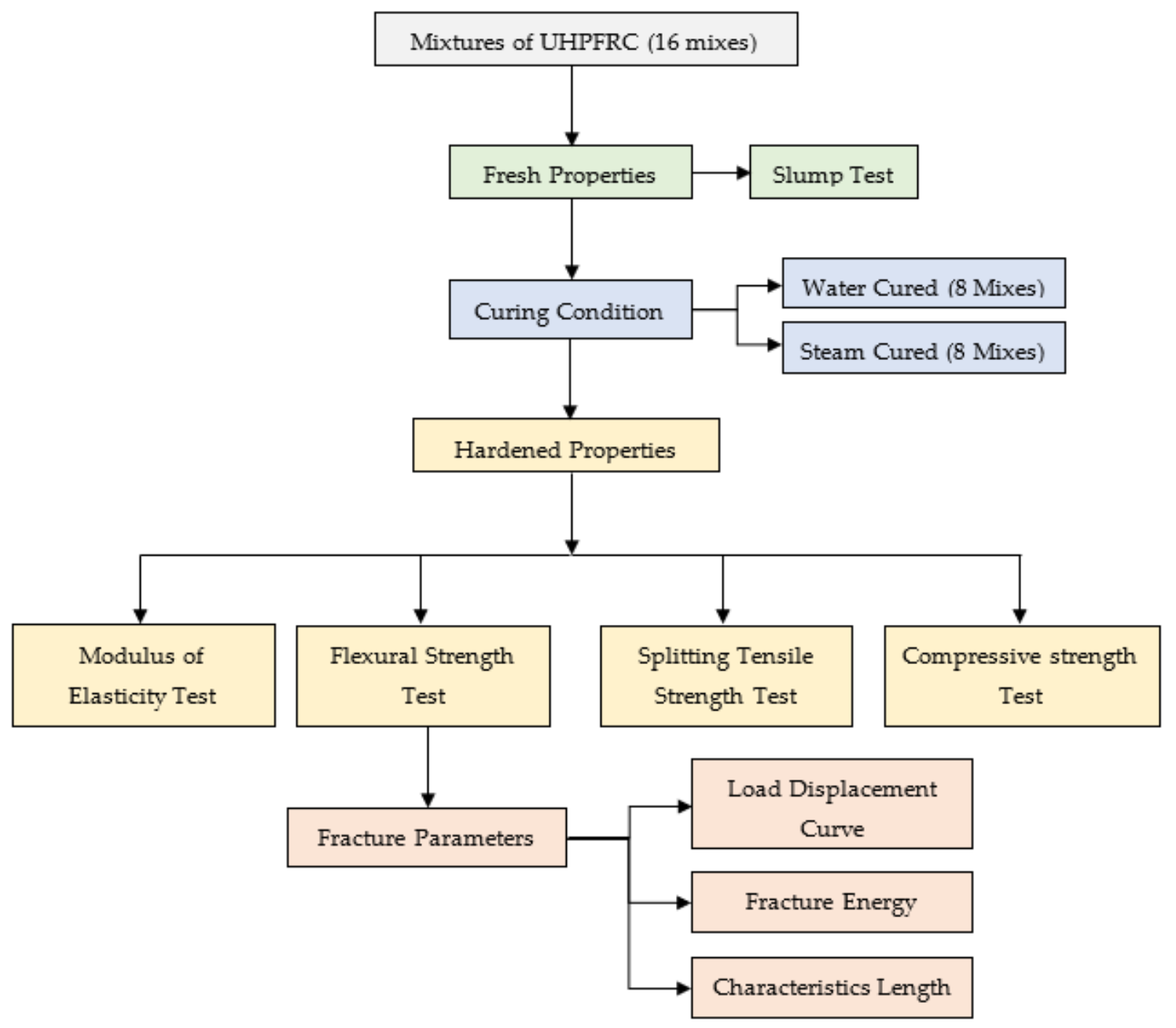

Figure 1. Flow chart diagram for the testing process conducted in this study.

For evaluating indirect surface energy for the cementitious products, facture energy is used [43]. To carry out the flexural strength test, an average of three prisms of $70 \mathrm{~mm} \times 70 \mathrm{~mm} \times 280 \mathrm{~mm}$ was tested with reference of RILEM 50- FMC /198 [44]. A $250 \mathrm{kN}$ capacity closed-loop machine was used for performing the test with a $0.02 \mathrm{~mm} /$ minute loading rate. To measure the displacement, a linear variable displacement transducer (LVDT) was fixed at the center of the beam. Figure 2 demonstrates the test details and test set up. Following RILEM [44], measuring the fracture energy $\left(\mathrm{G}_{\mathrm{F}}\right)$ of a notched beam by using a three-point loading system can be expressed as shown in Equation (1):

$$
\mathrm{G}_{\mathrm{F}}=\left(\mathrm{W}_{0}+\mathrm{mg} \delta_{\mathrm{s}}(\mathrm{S} / \mathrm{U})\right) / \mathrm{B}(\mathrm{W}-\mathrm{a})
$$

Hence, $\mathrm{W}_{0}, \mathrm{~m}, \mathrm{~g}$, and $\delta_{\mathrm{s}}$ are the area under the load-displacement curve, the beam mass, the gravity acceleration, and the beam deflection, correspondingly, whereas $\mathrm{S}$ is span, $\mathrm{U}$ is length, $\mathrm{B}$ is width, $\mathrm{W}$ is depth, and $\mathrm{a}$ is the notch depth of the beam. Equation (2) was implemented to calculated the net flexural strength, $\mathrm{f}_{\text {flex }}$, which the $\mathrm{P}_{\max }$ is the maximum load considering no notch sensitivity $[45,46]$. Furthermore, to measure the ductility, the characteristic length $\left(l_{\mathrm{ch}}\right)$ was calculated using Equation (3) which is a function of $\mathrm{E}, \mathrm{G}_{\mathrm{F}}$, and $f_{\text {st }}[47]$.

$$
\begin{gathered}
\mathrm{f}_{\text {flex }}=\left(3 \mathrm{P}_{\max } \mathrm{S}\right) /\left(2 \mathrm{~B}(\mathrm{~W}-\mathrm{a})^{2}\right) \\
\mathrm{l}_{\mathrm{ch}}=\left(\mathrm{EG}_{\mathrm{F}}\right) /\left(f_{\mathrm{st}}{ }^{2}\right)
\end{gathered}
$$




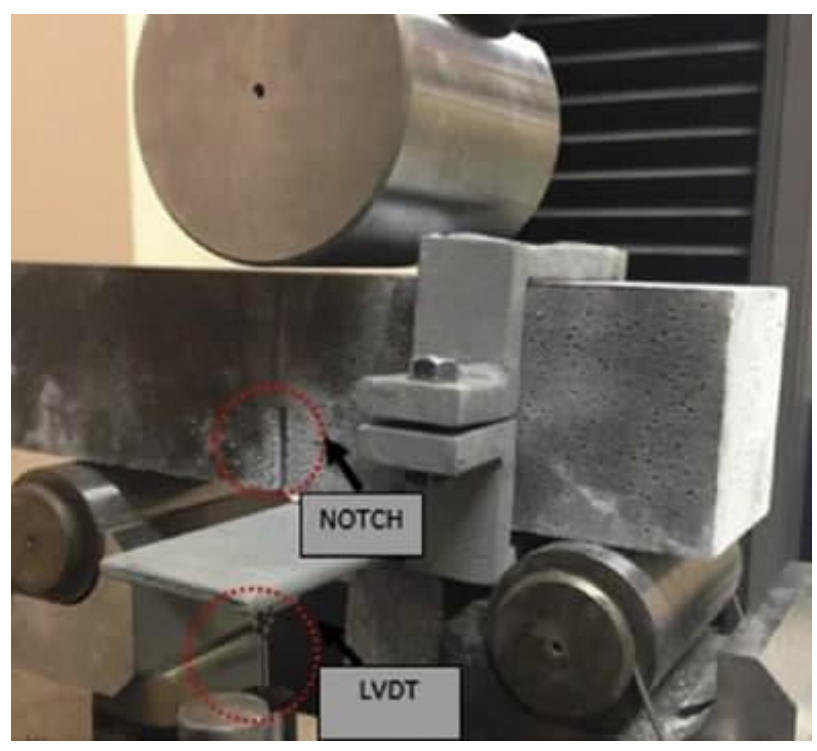

Figure 2. Test details and sample set up.

\section{Experimental Results and Discussion}

\subsection{Fresh Behavior of UHPFRC}

To achieve high-quality ultra-high performance concrete (UHPC) reinforced with $2 \%$ of MSF with the desired workability, the use of superplasticizer (SP) becomes a crucial step due to the low $\mathrm{w} / \mathrm{b}$ of UHPC. The desired flowability for all mixtures was achieved as kept as $18 \pm 1 \mathrm{~cm}$ by using a different amount of superplasticizer. The relation between increasing the amount of binder and the corresponding decrease in superplasticizer used is drawn in Figure 3. This inverse relationship may be attributed to the micro-level particles of silica fume (SF), which increased from 127.5 to $172.5 \mathrm{~kg} / \mathrm{m}^{3}$ responding to an increase in the binder content $\left(850-1150 \mathrm{~kg} / \mathrm{m}^{3}\right)$. Thus, due to their ultra-fine sizes that areshown in Table 1 compared to cement particles, small spherical silica particles may have helped to increase flowability not decreasing it [48]. In addition, the reason for the necessary increasing of SP with a greater increase in binder after $1150 \mathrm{~kg} / \mathrm{m}^{3}$ may be attributed to the better dispersion of micro silica particles at $1200 \mathrm{~kg} / \mathrm{m}^{3}$ of binder used. It was also reported that for the production of UHPC with $2 \%$ MSF and $1175 \mathrm{~kg} / \mathrm{m}^{3}$ binder content at $0.12 \mathrm{w} / \mathrm{b}$ the SP demand was nearly $70 \mathrm{~kg} / \mathrm{m}^{3}$ [28].

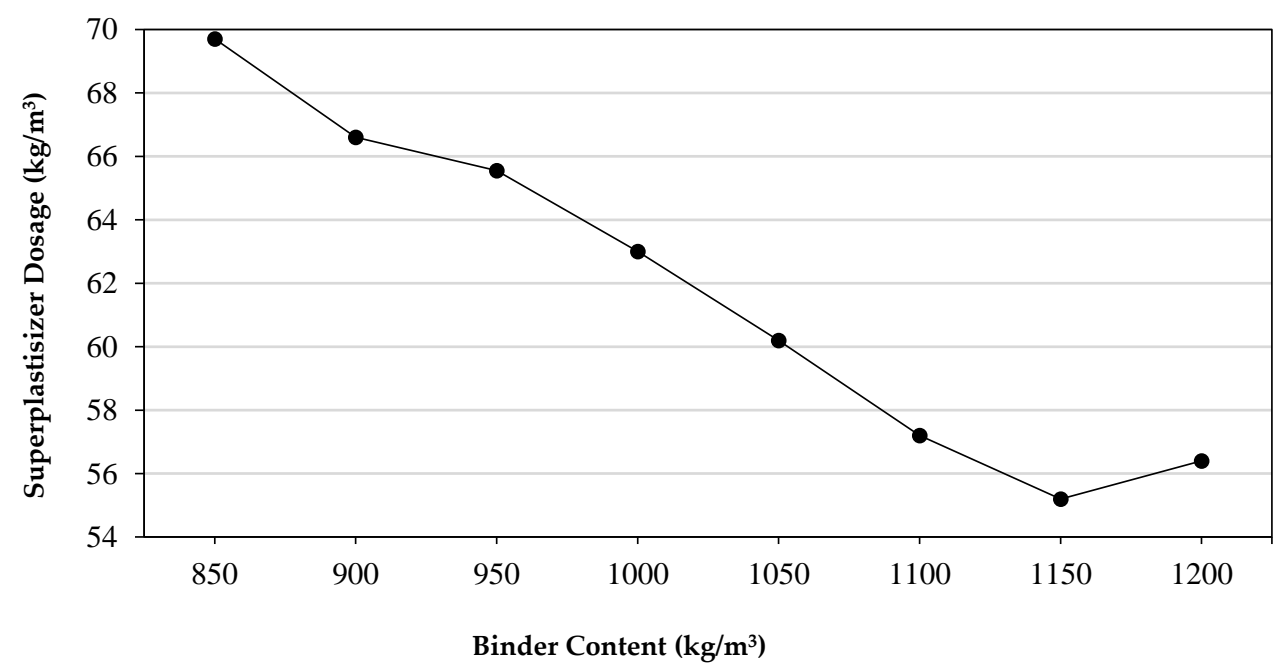

Figure 3. Super plasticizer demand versus binder content. 


\subsection{Compressive Strength}

Figure $4 a, b$ illustrate the compressive strength results of the ultra-high performance fiber reinforced concrete (UHPFRC) versus binder content for the two UHPFRC groups of water curing (WC-UHPFRC) and steam curing (SC-UHPFRC), correspondingly. The compressive strength results of SC concretes were very close to each other, whereas greater differences were noticed for the concretes cured via steam. At 28 days, the compressive strengths were 149 and $192 \mathrm{MPa}$ at $1150 \mathrm{~kg} / \mathrm{m}^{3}$ binder content as the highest values recorded in this study for the UHPFRCs cured by water and steam, respectively, while the lowest measurements were observed for WC-UHPFRC and SC-UHPFRC at $850 \mathrm{~kg} / \mathrm{m}^{3}$ of binder content as 129 and $165.5 \mathrm{MPa}$, respectively. Therefore, steam-cured concretes are superior to water-cured concretes. Likewise, Qadir et al. [28] studied water-cured UHPFRC having $1175 \mathrm{~kg} / \mathrm{m}^{3}$ binder content with $2 \%$ MSF content and $0.12 \mathrm{w} / \mathrm{b}$; a compressive strength of nearly $150 \mathrm{MPa}$ was achieved. Additionally, Yu et al. [49] observed that the use of $2 \%$ MSF in the UHPC increased the compressive strength from 99 to $120.8 \mathrm{MPa}$. Besides, with increasing binder content, lower improvement in the compressive strength was observed for the SC-UHPFRC compared to the WC-UHPFRC as the curing time prolonged. This can be attributed to the high early age strength gaining usually achieved when SC is employed. For example, at the age of 28 days, the $1150 \mathrm{WC}$ mixture had a $21.4 \%$ increase in compressive strength while the 1150SC had 6.3\% strength increments, compared to the 7 days results. Similar results were detected for UHPC with $1175 \mathrm{~kg} / \mathrm{m}^{3}$ binder and $2 \%$ MSF. For 28 days water curing, the compressive strength increment rate was $26 \%$, compared to the 7 days results [28]. The preferable nature of SC than WC is may be because of congestions of high hydration and pozzolanic reaction resulting from the ingredients of the ultra-amount of binder $\left(850-1200 \mathrm{~kg} / \mathrm{m}^{3}\right)$ and $S F\left(127.5-180 \mathrm{~kg} / \mathrm{m}^{3}\right)$ that activated dramatically by the high moisture and temperature of curing. Park et al. [50] stated that with increasing the curing temperature, the strength development of the UHPC was enhanced. Moreover, SC samples provide higher strengths compared to WC samples [51]. Regarding the binder content, a significant growth in compressive strength was observed as the binder content increased up to $1150 \mathrm{~kg} / \mathrm{m}^{3}$, then began to decrease. The faintly lower compressive strength of UHPFRC containing $1200 \mathrm{~kg} / \mathrm{m}^{3}$ binder may be related to inadequate spreading of the particles of the micro silica in the mix due to their small sizes. The dis-agglomeration of particles is vital to achieve a typical composite material; therefore, the required content of $\mathrm{SF}$ in the mixes were exceeded to consume the $\mathrm{Ca}(\mathrm{OH})_{2}$ compounds so as to produce more $\mathrm{C}-\mathrm{S}-\mathrm{H}$ gel. Consequently, it no longer influences the strength development of UHPFRC [31].

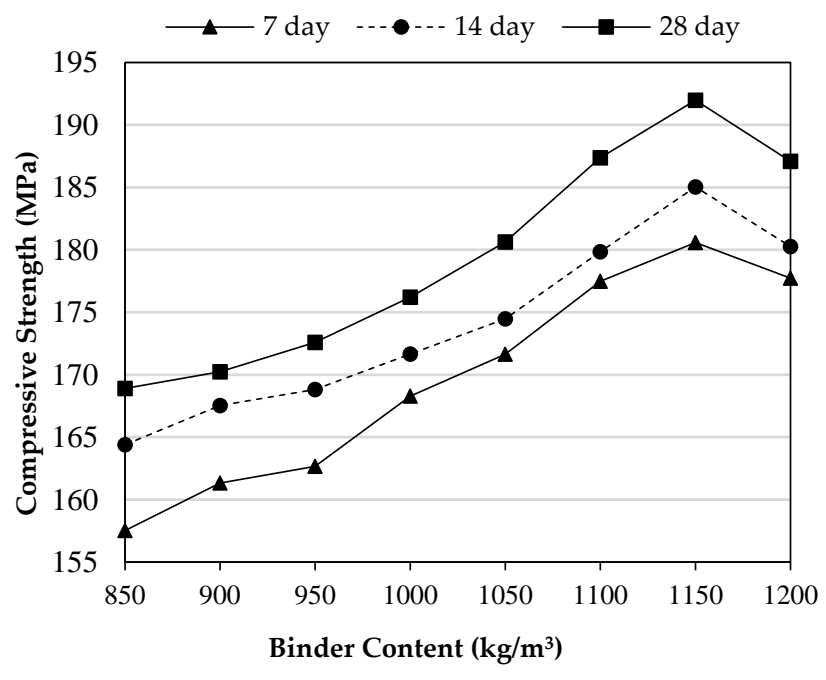

(a)

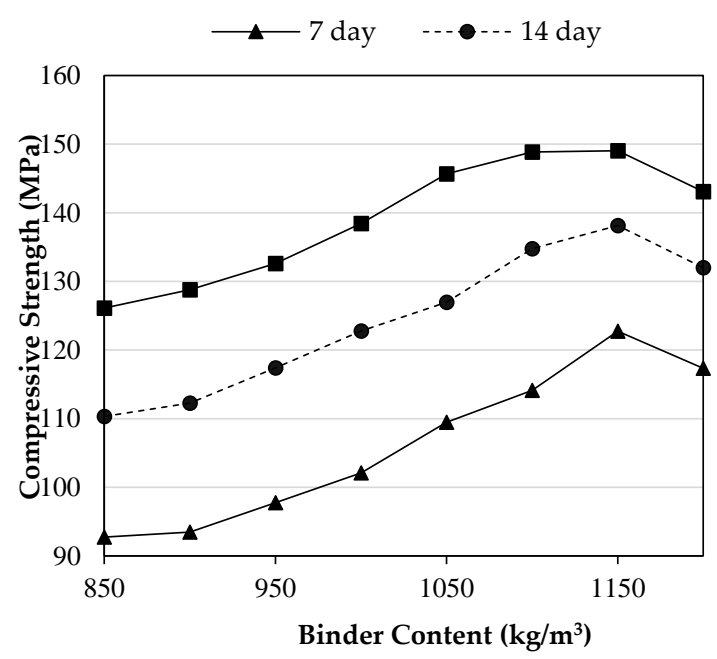

(b)

Figure 4. Compressive strength development versus binder content: (a) water-curing group; (b) steam-curing group. 


\subsection{Splitting Tensile Strength}

Commonly, the utilization of fibers improves the tensile strength of concretes. This might be attributed to the fact that the fibers enable blocking tensile cracks and then followed by limiting crack growth [28]. The variations of splitting tensile strength of UHPFRC with the different amount of binders and two curing conditions are given in Figure 5. It can be noticed that the changes of tensile strength results were dominated due to curing types and different binder content. A remarkable difference in the splitting tensile strength from 9.6 to $11.5 \mathrm{MPa}$ can be observed between the two types (WC to SC) of curing at $850 \mathrm{~kg} / \mathrm{m}^{3}$ binder content. The splitting tensile strengths for the above two groups (WC and SC) at $1200 \mathrm{~kg} / \mathrm{m}^{3}$ attained in this study were 11.3 and $12.8 \mathrm{MPa}$, respectively. Moreover, Gesoglu et al. [30] stated that for the water-cured UHPC reinforced with 2\% of MSF at $1200 \mathrm{~kg} / \mathrm{m}^{3}$ binder content, the splitting tensile strength was about $10.2 \mathrm{MPa}$. Also, for the micro glass fiber reinforced UHPC at $1175 \mathrm{~kg} / \mathrm{m}^{3}$ binder content cured via water, the splitting tensile strength was $11.79 \mathrm{MPa}$ [29]. Although, in WC-UHPFRC mixes, the rate of strength development with binder increment is higher than that of SC-UHPFRC, the steam-cured mixes show higher strength values. For example, increasing of binder with increments of $50 \mathrm{~kg} / \mathrm{m}^{3}$ over $850 \mathrm{~kg} / \mathrm{m}^{3}$ caused a systematic growth in tensile strength of concretes at 28 days by $3.7 \%, 10.6 \%, 12 \%, 15 \%, 16.8 \%, 19.4 \%$, and $17.2 \%$ for the water-cured group and $1.9 \%, 3.3 \%, 7 \%, 8.6 \%, 9.2 \%, 12.2 \%$, and $11 \%$ for the steam-cured group. Besides, adding more binders for the group of SC will not make sense compared to the tensile value gain from WC. This could be due to the hydration process and consuming $\mathrm{Ca}(\mathrm{OH})_{2}$ at $850 \mathrm{~kg} / \mathrm{m}^{3}$ binder content mostly completed and enhanced by high temperature and humidity. Just as in the compression condition, for the UHPFRC specimens it was observed that no vital improvement in splitting tensile strength was attained as the binder content increase beyond the $1150 \mathrm{~kg} / \mathrm{m}^{3}$, irrespective to the curing type. This might be attributed to the $15 \%$ of SF which constitutes $180 \mathrm{~kg} / \mathrm{m}^{3}$ out of the total binder content of $1200 \mathrm{~kg} / \mathrm{m}^{3}$, and this quantity of SF could be larger than the quantity needed to consume all cementitious products that resulted from the hydration process, thus leaving some of the SF particles with no chemical reaction [52]. This can also explain the higher content of SP needed to achieve the target slump at $1200 \mathrm{~kg} / \mathrm{m}^{3}$.

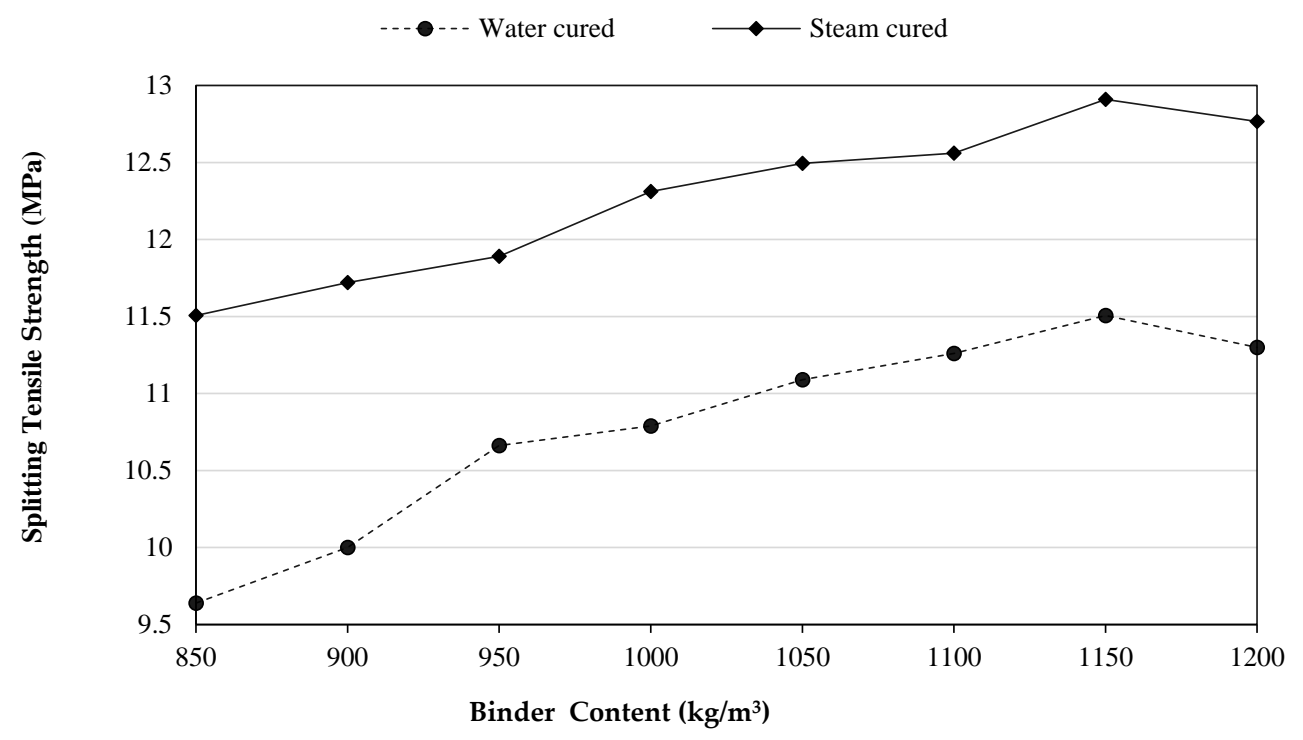

Figure 5. Splitting tensile strength development versus binder content.

\subsection{Modulus of Elasticity}

The Young modulus is considered one of the significant material characteristics employed in the design of structural concrete elements since it offers valuable indications about the deformation capacity of concrete in the elastic limit [53,54]. Figure 6 showed 
the 28 days static elastic modulus of UHPFRC via two curing types and various binder contents. The elastic modulus performance is in line with that observed in the strength results. Based on the increasing rate of binder content, strength development rate in WC-UHPFRC mixes were higher than SC-UHPFRC due to providing a high early age strength at $850 \mathrm{~kg} / \mathrm{m}^{3}$ by the SC-UHPFRC. Hence, the test measurements revealed that the influence of $1150 \mathrm{~kg} / \mathrm{m}^{3}$ water cured $(1150 \mathrm{WC})$ on the elastic modulus was nearly equivalent to $950 \mathrm{~kg} / \mathrm{m}^{3}$ of that binder that cured by steam (950SC). This may be attributed to the chemical and physical changes due to temperature and humidity effects on potential for the stress transfer. Additionally, the modulus of elasticity for the water-cured UHPFRC at $1150 \mathrm{~kg} / \mathrm{m}^{3}$ binder content achieved in this study was $41.15 \mathrm{GPa}$, whereas the modulus of elasticity for the same MSF content, $\mathrm{w} / \mathrm{b}$, and curing condition at $1175 \mathrm{~kg} / \mathrm{m}^{3}$ binder content achieved by Qadir et al. [28] was nearly $40 \mathrm{MPa}$.

Furthermore, it was detected that the effect of an increase in the binder content resulted in increasing the concrete's elastic modulus. The increasing tendency continues until the total binder content reaches up to $1150 \mathrm{~kg} / \mathrm{m}^{3}$, after which a drop began. At $1150 \mathrm{~kg} / \mathrm{m}^{3}$ binder content, the UHPFRC had maximum elastic modulus and improved by $35 \%$ and $21.1 \%$ for the WC and SC groups, correspondingly, when compared to their controls $\left(850 \mathrm{~kg} / \mathrm{m}^{3}\right)$. It is well recognized that the hydration process has a large impact on the mechanical characteristics of cement-based ingredients, and an appropriate proportion of crystals to non-crystals is preferable to produce higher values [55]. Due to this, an optimum amount of binder can attain an appropriate crystal-to-non-crystal ratio to achieve a greater elastic modulus. Consequently, it is concluded that a huge binder content is disadvantageous to the modulus of elasticity achievement of cement-based materials as observed with the mixtures contained $1200 \mathrm{~kg} / \mathrm{m}^{3}$ of binder.

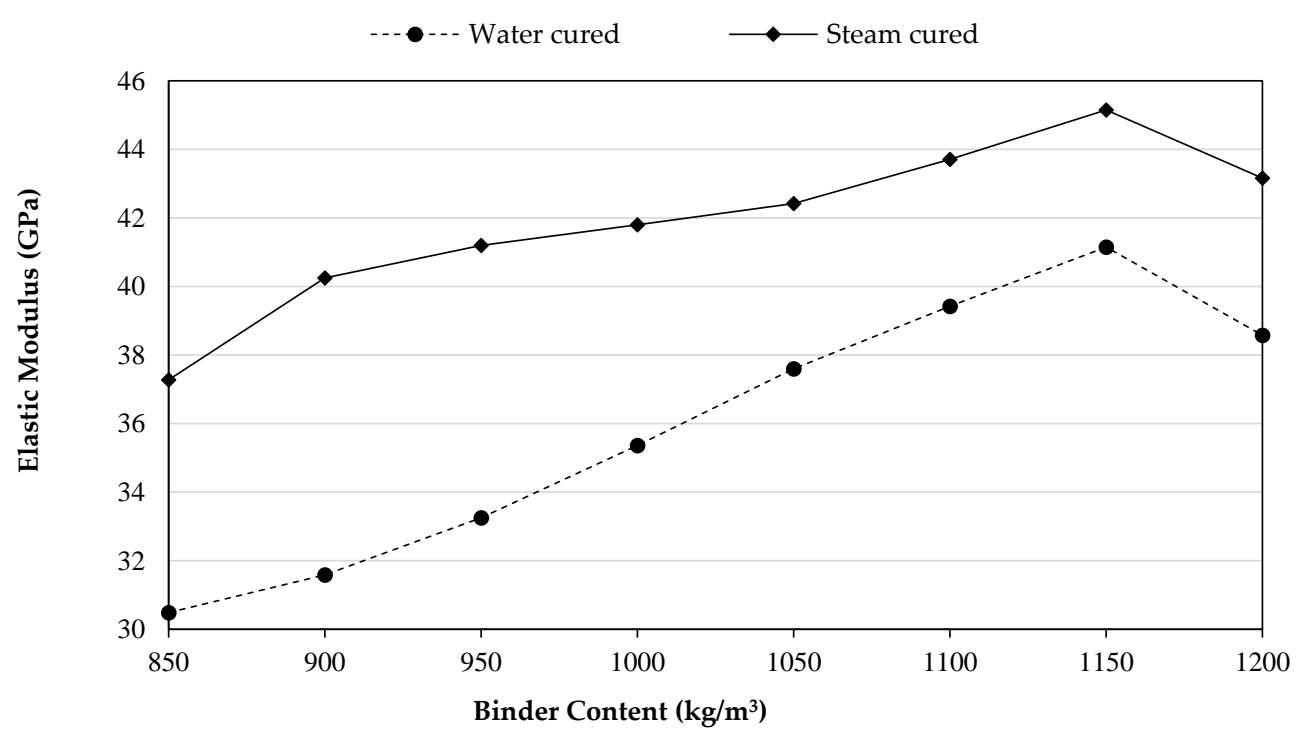

Figure 6. Elastic modulus development versus binder content.

\subsection{Modulus of Rupture (Flexural Strength)}

The UHPFRC results of the two groups of this experimental research work are in line with the earlier research on improving the flexural strength of UHPCs reinforced with MSF especially at a high rate of binder content [28-30]. The effects of binder content on the flexural strength of the UHPCs including $2 \%$ of MSF cured via steam and water are illustrated in Figure 7. The preference of SC-UHPFRC over WCOUHPFRC which was noticed from the test results is probably due to the high temperature of steam has motivated the pozzolanic reaction of the calcium hydroxide shaped through the hydration process of cementitious products. In addition, the reaction may take place between unwanted $\mathrm{Ca}(\mathrm{OH})_{2}$ and very fine quartz aggregates as well as SF due to hot steam curing conditions [56]. Furthermore, 
these pozzolanic reactions may lead to a denser C-S-H microstructure that results in an earlier development of strength gaining.

Additionally, it was found that the modulus of rupture (flexural strength) of UHPFRCs continuously increased up to $1150 \mathrm{~kg} / \mathrm{m}^{3}$ of binder content, irrespective to the curing types. Beyond that, the flexural strength values start to drop down so that utilizing $1200 \mathrm{~kg} / \mathrm{m}^{3}$ of binder declined the 28 days net flexural strength. For example, UHPFRCs with $1150 \mathrm{~kg} / \mathrm{m}^{3}$ of binder content reached the maximum flexural strength of 12.7 and $16.2 \mathrm{MPa}$, which reduced to 12.2 and $15.3 \mathrm{MPa}$, when the total binder reached to $1200 \mathrm{~kg} / \mathrm{m}^{3}$, for the WCUHPFRC and SC-UHPFRC groups, respectively. Moreover, for UHPC reinforced with the same content of MSF and $0.195 \mathrm{w} / \mathrm{b}$ at $1200 \mathrm{~kg} / \mathrm{m}^{3}$ binder content, the flexural strength was $8.15 \mathrm{MPa}$ for the 28 days water-cured samples [30]. On the other hand, the reason behind the decline in the flexural strength might be attributed to the amount of binder particles existing in the mixture. They are shown to be greater than the amount necessary to link with the other UHPFRC constituents through the process of hydration. Thus, leading to excess silica leaching out and causing a decrease in strength. Additionally, it may be because of the defects caused in a dispersion of binders that causes weak zones [52].

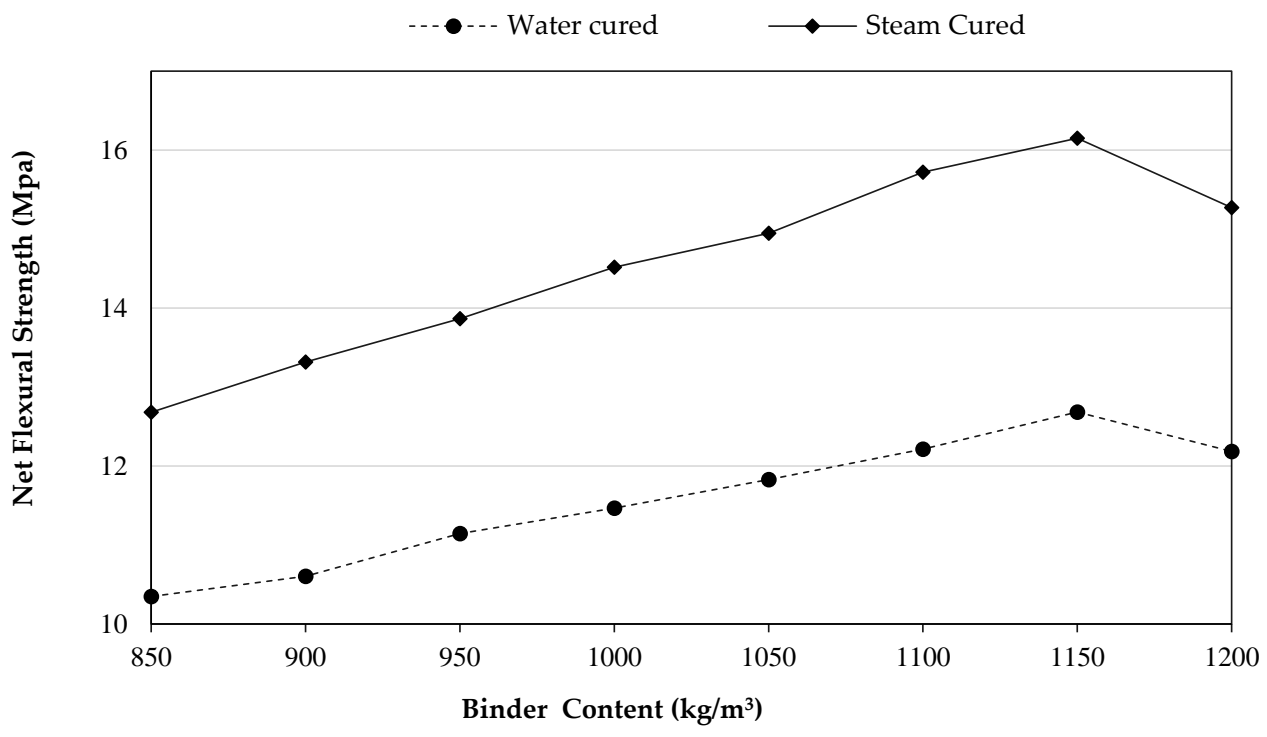

Figure 7. Flexural strength development versus binder content.

\subsection{Load-Displacement Curves}

The load-deflection curves measured at each loading stage by means of LVDTs for the mixes with different binder amounts of UHPFRC cured via water and steam are given in Figure 8a,b. The LVDTs were set up at the mid-span of the prisms. Regardless of the curing type, the stiffness and toughness are improved via the addition of $2 \%$ of MSF in the matrix of UHPC [57]. It can be noted at the initiation of cracking, i.e., at post-peak loads, that the shape of the curves changed into the zigzag form [28]. This may be due to use of MSFs which can significantly tie the micro cracks and enhance the load capacity of the beam specimens when thousands of fibers will stand against the enlargement of cracks. Furthermore, the UHPFRC having $\%$ MGF with $0.12 \mathrm{w} / \mathrm{b}$ at $1150 \mathrm{~kg} / \mathrm{m}^{3}$ binder content conducted in this study had an area under the curve, a maximum displacement, and a peak load of $4285.1 \mathrm{kN} . \mathrm{mm}, 4.83364 \mathrm{~mm}$, and $5.2 \mathrm{kN}$, respectively, for the water-cured group. Similarly, for the same curing condition, $\mathrm{w} / \mathrm{b}$, and $1175 \mathrm{~kg} / \mathrm{m}^{3}$ binder content, the UHPC with $2 \%$ micro glass fiber content had an area under the curve, a maximum displacement, and a peak load maximum peak load of $895.5 \mathrm{kN} . \mathrm{mm}, 1.1 \mathrm{~mm}$, and $6.4 \mathrm{kN}$, correspondingly [29].

On the other hand, irrespective of the binder content, it can be seen from the abovementioned figures that SC-UHPFRC showed higher performance than WC-UHPFRC, including 
all important parameters found via load-displacement curves as shown in Table 4 . This probably referred to the high-temperature $\left(90^{\circ} \mathrm{C}\right)$ of the steam curing regime provided in a short curing period. Also, it can observed that the peak remarkably depends on the quantity of binder (see Table 4).

Moreover, referring to the binder content, some extent in the pre-peak and post-peak region of the curvature has occurred. The beam load-displacement curves with utilizing a higher binder content dominated a steady decrease in the curve beyond the peak load versus a sharper decrease in the mixtures holding the lower amount of binders. This may be due to the increasing of energy required for debonding UHPFRC components that contained a high volume of binders. Furthermore, the pre-peak and the early post-peak areas in the curves essentially influenced the microcracks and the crack development. Whereas the decrease in the slope at the end of the softened branches could be due to the degree of interlocks between aggregates and fiber content [58], where the binder amounts have a relatively significant role in both phenomena.

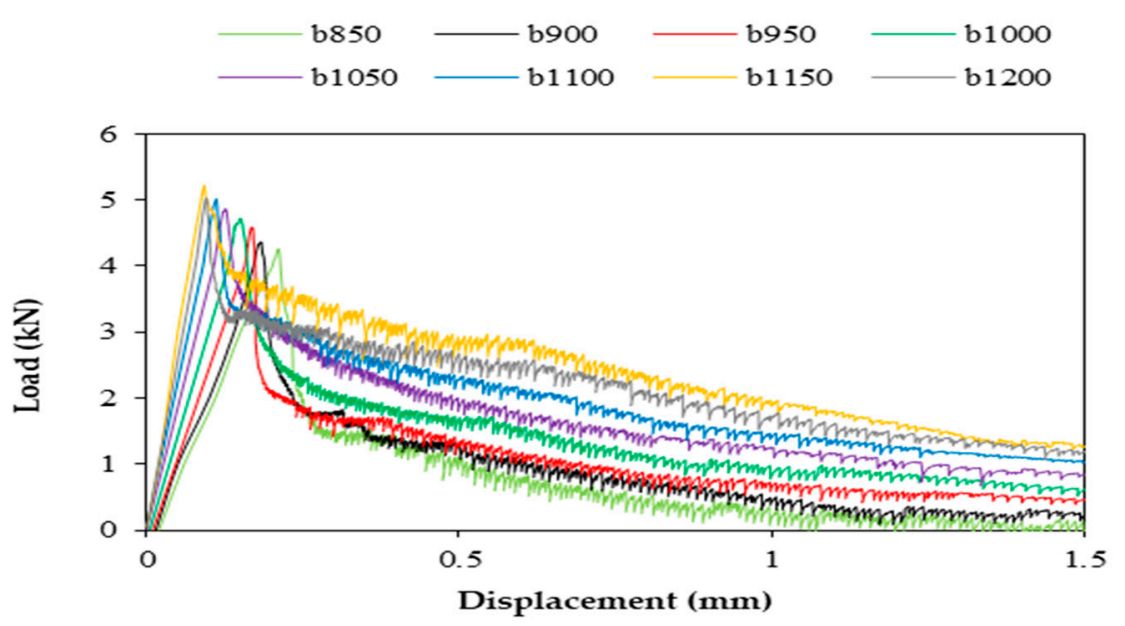

(a)

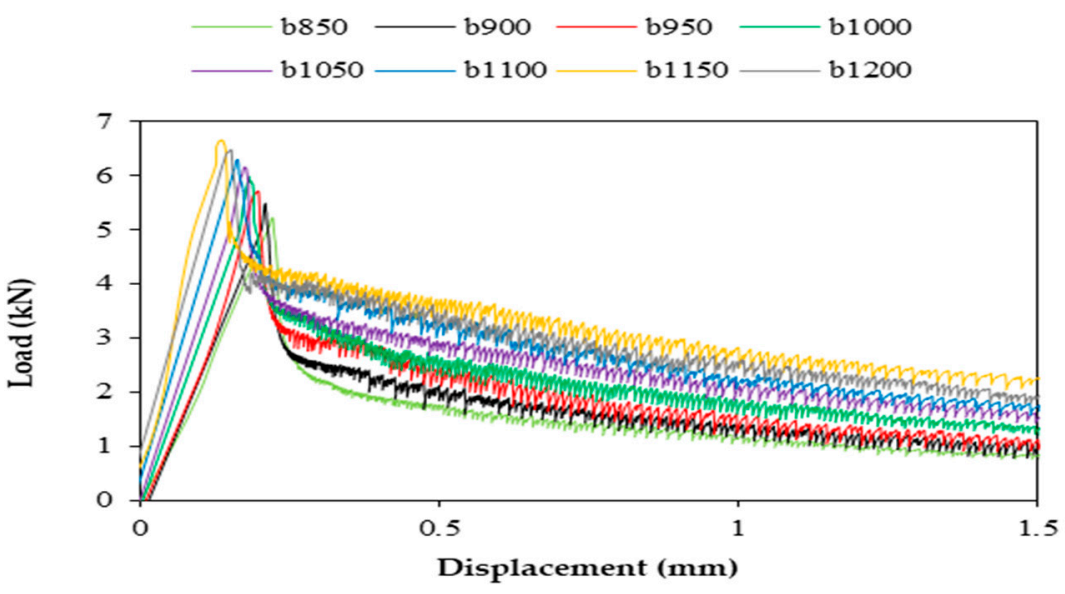

(b)

Figure 8. Load versus displacement curves of UHPFRC: (a) water-curing group; (b) steam-curing group. 
Table 4. Load-displacement parameters of UHPFRC.

\begin{tabular}{cccc}
\hline & Area under the Curve & Maximum Disp. & $\mathbf{P}_{\mathbf{m a x}}$ \\
\cline { 2 - 4 } CODE & $\mathbf{W}_{\mathbf{0}}$ & $\boldsymbol{\delta}_{\mathbf{s}}$ & $\mathbf{k N}$ \\
\hline 850WC & 2487.0 & 5.64731 & 4.3 \\
900WC & 2744.0 & 5.14114 & 4.4 \\
950WC & 3039.0 & 5.00372 & 4.6 \\
1000WC & 3150.0 & 6.08267 & 4.9 \\
1050WC & 3340.0 & 5.32244 & 5.0 \\
1100WC & 3697.5 & 4.7947 & 5.2 \\
1150WC & 4285.1 & 4.83364 & 5.0 \\
1200WC & 4038.6 & 4.98909 & 5.2 \\
850SC & 3009.0 & 5.47963 & 5.5 \\
900SC & 3274.0 & 5.17962 & 5.7 \\
950SC & 3387.9 & 5.27415 & 6.0 \\
1000SC & 3799.3 & 5.23746 & 6.2 \\
1050SC & 3951.1 & 5.34784 & 6.5 \\
1100SC & 4275.7 & 5.54869 & 6.6 \\
1150SC & 5116.1 & 5.09704 & 6.3 \\
1200SC & 4766.4 & 4.90861 &
\end{tabular}

\subsection{Fracture Energy}

The fracture energy $\left(G_{F}\right)$ is distinct as the material's capacity to absorb the energy in the post-crack region, and it can be characterized to absorb the energy by the material for the period of failure. Conversely, the ductility behavior of concrete is specified by the fracture parameters, the high value of $G_{F}$ refers to the high the ductile behavior of the concrete $[30,31]$. In this experimental work, the $\mathrm{G}_{\mathrm{F}}$ values of UHPFRC versus different binder content for all the mixes of WC and SC are presented in Figure 9. With regard to the curing types, the effect of SC on GF is superior than water curing because steam curing boosts the pozzolanic reaction, improves the microstructure of the compounds, and consumes $\mathrm{Ca}(\mathrm{OH})_{2}$ rapidly; thus, it enhances the fracture energy greatly compared to the results of the WC groups.

Furthermore, it is estimated, similar to the aforementioned strength test results, that the UHPFRC will improve significantly with increasing binder content up to $1150 \mathrm{~kg} / \mathrm{m}^{3}$ in which the maximum values were recorded, beyond that limit the GF values were declined, irrespective of the curing types. Additionally, the development rate of fracture parameters for the UHPC is greater than other mechanical properties including compressive strength, tensile strength, and modulus of elasticity. This is due to the fact that fracture properties mostly rely on bond strength and arresting cracks, which can be improved by utilizing the high volume of MSF and ultra binder content, whereas the other properties depend on improving the interfacial transition zone (ITZ) that fibers do not contribute directly to improve [28]. The GF values improved by $9.3,20.5,25.6,32.1,45.3,67.7$, and $58.5 \%$ as well as 8.2, 11.9, 25, 29.9, 40.4, 66.8, and $55.5 \%$ for the WC and SC groups of UHPFRC, correspondingly, compared to their reference mixtures $\left(850 \mathrm{~kg} / \mathrm{m}^{3}\right)$ at 28 days, when 900 , $1000,1050,1100,1150$ and $1200 \mathrm{~kg} / \mathrm{m}^{3}$ of binder were combined. The main reason behind this enhancement in GF may be attributed to the filling properties of SF, when their amount increased from 127.5 to $180 \mathrm{~kg} / \mathrm{m}^{3}$ responding to change in the binder content from 850 to $1200 \mathrm{~kg} / \mathrm{m}^{3}$. Consequently, the ITZ and cement paste may have a strength development, then cracks were desired to pass through the aggregate particles rather than the ITZ and cement matrix [31]. Besides, the reason behind the adverse performance of UHPFRCs after $1150 \mathrm{~kg} / \mathrm{m}^{3}\left(\right.$ at $\left.1200 \mathrm{~kg} / \mathrm{m}^{3}\right)$ may be related to the fact that there is a much greater necessity amount of silica inside concrete, and extra silica will leach out, resulting in forming weak zones through the matrix. This could be the reason for the decline in the values of Gf at $1200 \mathrm{~kg} / \mathrm{m}^{3}$ as can be seen in Figure 9. 


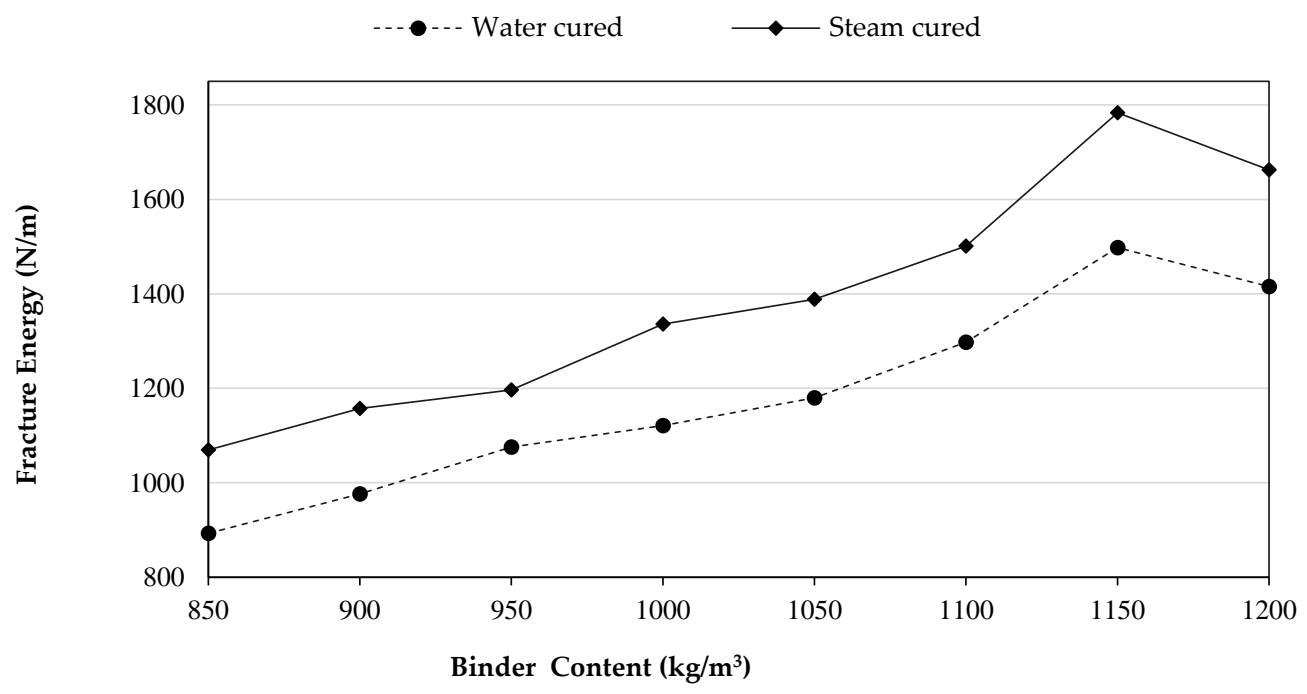

Figure 9. Fracture energy development versus binder content.

\subsection{Characteristic Length, $l_{\text {ch }}$}

Characteristic length $\left(l_{\mathrm{ch}}\right)$ is a decent property to evaluate the brittleness of concrete materials. Concrete is expected to have less brittleness whenever its $1_{\mathrm{ch}}$ is high. As presented in Equation (3), the characteristic length of concrete is directly proportional with fracture energy and modulus of elasticity, whereas it has an inverse relation with tensile strength.

The characteristic length values of the UHPCs including $2 \%$ of micro steel fibers are illustrated in Figure 10 with respect to the different binder contents that were exposed to two curing groups of water and steam. For instance, the $l_{\mathrm{ch}}$ for the water-cured samples at $1150 \mathrm{~kg} / \mathrm{m}^{3}$ attained in this study was $483 \mathrm{~mm}$. Besides, the $1_{\mathrm{ch}}$ for the micro steel fiber reinforced UHPC that cured via water at $1175 \mathrm{~kg} / \mathrm{m}^{3}$ binder content was about $580 \mathrm{~mm}$ [28]. Based on the curing types, it was observed that the differences were minimal, as is noticeable from the ductility results shown in the above figure; however, steam curing achieved higher values than water curing. The occurrence of such behavior could be due to the fact that the hydration process probably is more activated and continued for a period of time in the steam curing condition. In addition, the pozzolanic reaction resulting from the ingredients of SF in the UHPFRC mixtures will be enhanced energetically by the high moisture and temperature of curing, and it may directly affect the brittleness of concrete.

Alternatively, the effects of increasing binder from 850 up to $1150 \mathrm{~kg} / \mathrm{m}^{3}$ seemed to be significant on increasing the ductility 'decreasing brittleness' of UHPFRCs as the $1_{\mathrm{ch}}$ values range between 293 and $465.5 \mathrm{~mm}$ and 301.1 and $483.2 \mathrm{~mm}$ for the water and steam curing groups, respectively; then, after adding more binder $\left(1200 \mathrm{~kg} / \mathrm{m}^{3}\right)$, the tendency for brittleness increased. This behavior of enhancement of ductility may be referred to the binary effects of the high volume content of SF and cement accompanying the very low $\mathrm{w} / \mathrm{b}$ of 0.12 , thus leading to converting material being more ductile. The reason for concrete's tendency for brittleness at $1200 \mathrm{~kg} / \mathrm{m}^{3}$ could be because of the fact that any extra amount of SF more than $172.5 \mathrm{~kg} / \mathrm{m}^{3}$, which contributes $15 \%$ of the weight of the total binder of $1150 \mathrm{~kg} / \mathrm{m}^{3}$, may work as a lubricant area to slippage the other concrete constituents over each other. There is a gap of research on the characteristic length of UHPC, but many reports have tackled it for conventional concretes. For instance, for compressive strengths that range between 40 and $80 \mathrm{MPa}$, the $1_{\mathrm{ch}}$ was measured by Zhang et al. [59] that ranged from 412 to $235 \mathrm{~mm}$, and it was also ranged from 200 to $500 \mathrm{~mm}$ by Petersson [60]. Additionally, for the high strength self-compacting concretes including plastic, Faraj et al. [61] stated that $1_{\mathrm{ch}}$ is in the range of 85 to $178 \mathrm{~mm}$. 


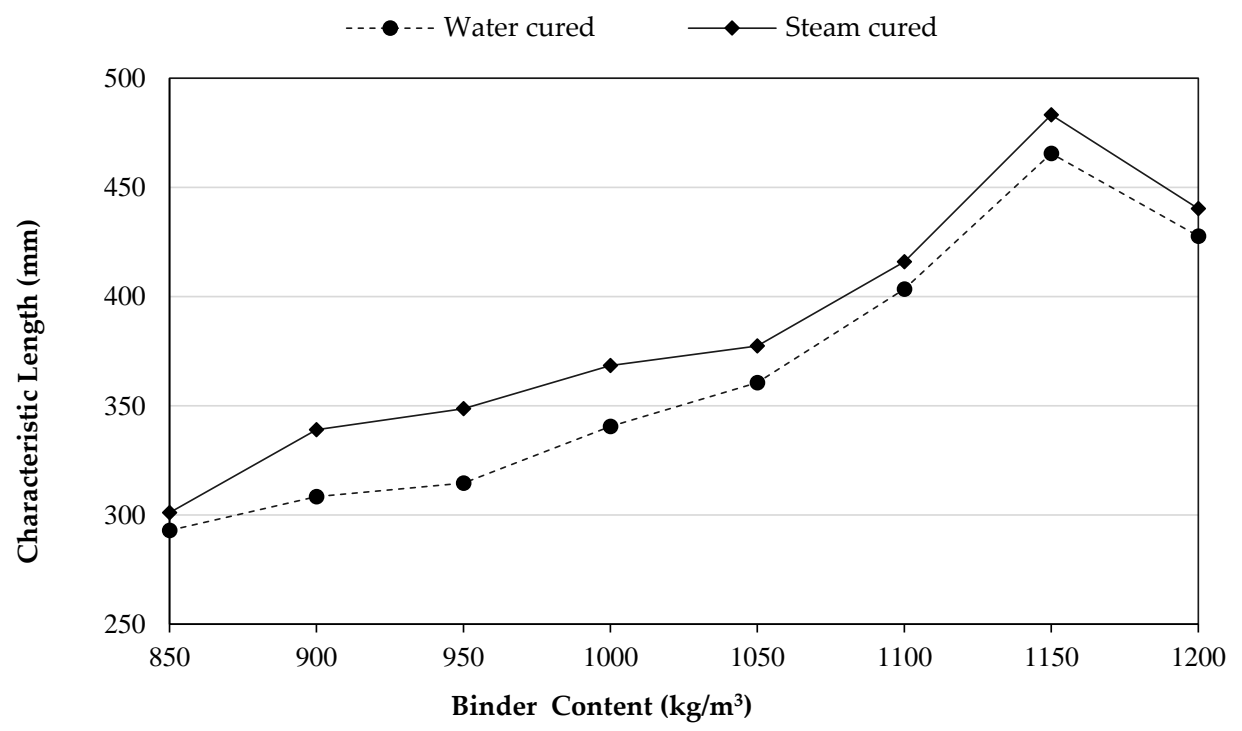

Figure 10. Characteristic length development versus binder content.

\section{Conclusions}

In this experimental research work, the impact of different binder content (comprising $85 \%$ cement $+15 \%$ SF) and curing types on the performance of UHPC reinforced with $2 \% \mathrm{MSF}$ at $0.12 \mathrm{w} / \mathrm{b}$ has been observed. The findings attained in this research can be summarized as follows:

1. An inverse relation occurred with an increasing amount of binder via super plasticizer. This may be attributed to the increase in SF responding to the increase in the binder content. Moreover, the reason for the necessary increasing of SP with a greater increase in binder after $1150 \mathrm{~kg} / \mathrm{m}^{3}$ may be attributed to the dispersion of SF at $1200 \mathrm{~kg} / \mathrm{m}^{3}$ of binder content.

2. In the present study, the performance of SC-UHPFRC was much better than WCUHPFRC. Therefore, better results were achieved for all the measured properties conducted in this study for the mixes cured by steam. This might be because of the potential of high hydration and the pozzolanical reaction of the ultra-amount of binder $\left(850-1200 \mathrm{~kg} / \mathrm{m}^{3}\right)$ that was activated by the high moisture and temperature of curing.

3. SC-UHPFRC mixes had considerable high early strength compared to WC-UHPFRC. However, based on the binder content, it was observed that WC-UHPFRC had a significantly higher rate of strength development.

4. It was observed that there was a systematic growth in the mechanical properties and ductility behavior of UHPFRC with increasing the binder contents up to $1150 \mathrm{~kg} / \mathrm{m}^{3}$ and then the results were dropped. This behavior of UHPFRC containing $1200 \mathrm{~kg} / \mathrm{m}^{3}$ binder could be because of the inadequate spreading particles of SF or it could be due to the fact that the increase in SF content has no more role in forming C-S-H gel as all $\mathrm{CH}$ compounds have been consumed.

5. The highest compressive strengths noticed at $1150 \mathrm{~kg} / \mathrm{m}^{3}$ of binder content were 149 and $192 \mathrm{MPa}$, while the lowest were 129 and $165.5 \mathrm{MPa}$ at $850 \mathrm{~kg} / \mathrm{m}^{3}$ of the binder amount for the WC-UHPFRCs and SC-UHPFRCs conditions, respectively.

6. Increasing the binder content with an increment of $50 \mathrm{~kg} / \mathrm{m}^{3}$ over $850 \mathrm{~kg} / \mathrm{m}^{3}$ caused a systematic growth in the splitting tensile strength of concrete by $3.7 \%, 10.6 \%, 12 \%$, $15 \%, 16.8 \%, 19.4 \%$, and $17.2 \%$ for the WC-UHPFRC group and $1.9 \%, 3.3 \%, 7 \%, 8.6 \%$, $9.2 \%, 12.2 \%$, and $11 \%$ for the SC-UHPFRC group.

7. The test results of UHPFRC revealed that the influence of $1150 \mathrm{~kg} / \mathrm{m}^{3}$ of binder cured by water (1150WC) on the elastic modulus was almost equivalent to $950 \mathrm{~kg} / \mathrm{m}^{3}$ of binder content cured by steam (950SC). 
8. The flexural strength of UHPFRC with $1150 \mathrm{~kg} / \mathrm{m}^{3}$ binder had the highest values of 12.7 and 16.2 MPa then reduced to 12.2 and $15.3 \mathrm{MPa}$ at $1200 \mathrm{~kg} / \mathrm{m}^{3}$ binder content, for the WC-UHPFRC and SC-UHPFRC, respectively.

9. The toughness of the UHPFRC was improved with using more binder content as the area under the curve and the peak load were increased. SC-UHPFRC provided higher values than WC-UHPFRC. Moreover, at the post-peak region in the loaddisplacement curves, the curves have a zigzag form. Such form might have occurred because of the mechanism of micro cracks due to the crack-bridging process over the micro steel fibers.

10. More ductile UHPFRC can be achieved with increasing the binder content, irrespective of the curing types. The optimum values of UHPFRC were obtained at $1150 \mathrm{~kg} / \mathrm{m}^{3}$ binder content. For instance, the GF improved by $67.7 \%$ and $66.8 \%$ for the water- and steam-cured groups, respectively, compared to their reference mixtures $\left(850 \mathrm{~kg} / \mathrm{m}^{3}\right)$. Beyond that binder content, GF values decreased.

11. The range of the characteristic length of UHPFRC was between 293 and $465.5 \mathrm{~mm}$ and 301.1 and $483.2 \mathrm{~mm}$ for the binder content ranging from 850 to $1150 \mathrm{~kg} / \mathrm{m}^{3}$ for the concretes cured via water and steam, respectively. Adding more binders $\left(1200 \mathrm{~kg} / \mathrm{m}^{3}\right)$ increases the tendency of concrete to be brittle.

Author Contributions: Conceptualization, A.F.H.S., A.A.M., K.H.Y. and R.H.F.; methodology, A.F.H.S., A.A.M., K.H.Y. and R.H.F.; software, A.F.H.S., A.A.M., K.H.Y. and R.H.F.; validation, A.M.; formal analysis, A.F.H.S., A.A.M., K.H.Y. and R.H.F.; investigation, A.F.H.S., A.A.M., K.H.Y. and R.H.F.; resources, A.M.; data curation, A.F.H.S., A.A.M., K.H.Y. and R.H.F.; writing-original draft preparation, A.F.H.S., A.A.M., K.H.Y. and R.H.F.; writing-review and editing, A.F.H.S., R.H.F., K.H.Y., A.A.M. and A.M.; visualization, A.F.H.S., A.A.M., K.H.Y. and R.H.F.; supervision, A.F.H.S., A.A.M., R.H.F. and A.M.; project administration, A.M.; funding acquisition, A.M. All authors have read and agreed to the published version of the manuscript.

Funding: This research received no funding.

Institutional Review Board Statement: Not applicable.

Informed Consent Statement: Not applicable.

Data Availability Statement: Data can be obtained from corresponding authors upon reasonable request.

Acknowledgments: Open Access Funding by the Publication Fund of the TU Dresden. Amir Mosavi would like to thank Alexander von Humboldt Foundation.

Conflicts of Interest: The authors declare no conflict of interest.

\section{References}

1. Xiao, J.; Schneider, H.; Dönnecke, C.; König, G. Wedge splitting test on fracture behaviour of ultra high strength concrete. Constr. Build. Mater. 2004, 18, 359-365. [CrossRef]

2. Richard, P.; Cheyrezy, M.H. Reactive powder concretes with high ductility and 200-800 Mpa compressive strength. Proc. V. Mohan Malhotra Symp. 1994, 144, 507-518. [CrossRef]

3. Ahlborn, T.M.; Peuse, E.J.; Misson, D.L. Ultra-High Performance Concrete for Michigan Bridges, Material Performance: Phase I; Michigan Department of Transportation: Lansing, MI, USA, 2008.

4. Schmidt, M.; Fehling, E. Ultra-high-performance concrete: Research, development and application in Europe. Seventh Int. Symp. Util. High Strength High Perform. Concr. 2005, 228, 51-78. [CrossRef]

5. Zhao, S.; Sun, W. Nano-mechanical behavior of a green ultra-high performance concrete. Constr. Build. Mater. 2014, 63, 150-160. [CrossRef]

6. Aghdasi, P.; Ostertag, C.P. Green ultra-high performance fiber-reinforced concrete (G-UHP-FRC). Constr. Build. Mater. 2018, 190, 246-254. [CrossRef]

7. Bonneau, O.; Poulin, C., Jr.; Dugat, M.; Tcin, P.C.A. Reactive Powder Concretes: From Theory to Practice. Concr. Int. 1996, 18, 47-49.

8. Luigi, C.; Troli, R.; Collepardi, S.; Borsoi, A.; Cerulli, T.; Collepardi, M. Innovative cementitious materials from HPC to RPCPart II. The effect of cement and silica fume type on the compressive strength of reactive powder concrete. Ind. Ital. Cem. 1996, $66,112-125$.

9. Long, G.; Wang, X.; Xie, Y. Very-high-performance concrete with ultrafine powders. Cem. Concr. Res. 2002, 32, 601-605. [CrossRef] 
10. Bahedh, M.A.; Jaafar, M.S. Ultra high-performance concrete utilizing fly ash as cement replacement under autoclaving technique. Case Stud. Constr. Mater. 2018, 9, e00202. [CrossRef]

11. Habel, K.; Viviani, M.; Denarié, E.; Brühwiler, E. Development of the mechanical properties of an Ultra-High Performance Fiber Reinforced Concrete (UHPFRC). Cem. Concr. Res. 2006, 36, 1362-1370. [CrossRef]

12. Allena, S.; Newtson, C. Ultra-High Strength Concrete Mixtures Using Local Materials. J. Civil Eng. Archit. 2010, 5, 322-330.

13. Yoo, D.-Y.; Banthia, N.; Yoon, Y.-S. Flexural behavior of ultra-high-performance fiber-reinforced concrete beams reinforced with GFRP and steel rebars. Eng. Struct. 2016, 111, 246-262. [CrossRef]

14. Yu, R.; Spiesz, P.; Brouwers, H.J.H. Energy absorption capacity of a sustainable Ultra-High Performance Fibre Reinforced Concrete (UHPFRC) in quasi-static mode and under high velocity projectile impact. Cem. Concr. Compos. 2016, 68, 109-122. [CrossRef]

15. Brandt, A.M. Fibre reinforced cement-based (FRC) composites after over 40 years of development in building and civil engineering. Compos. Struct. 2008, 86, 3-9. [CrossRef]

16. Won, J.-P.; Hong, B.-T.; Choi, T.-J.; Lee, S.-J.; Kang, J.-W. Flexural behaviour of amorphous micro-steel fibre-reinforced cement composites. Compos. Struct. 2012, 94, 1443-1449. [CrossRef]

17. Tassew, S.T.; Lubell, A.S. Mechanical properties of glass fiber reinforced ceramic concrete. Constr. Build. Mater. 2014, 51, 215-224. [CrossRef]

18. Sucharda, O. Identification of fracture mechanic properties of concrete and analysis of shear capacity of reinforced concrete beams without transverse reinforcement. Materials 2020, 13, 2788. [CrossRef] [PubMed]

19. Van Tuan, N.; Ye, G.; van Breugel, K.; Copuroglu, O. Hydration and microstructure of ultra high performance concrete incorporating rice husk ash. Cem. Concr. Res. 2011, 41, 1104-1111. [CrossRef]

20. Meleka, N.N.; Bashandy, A.A.; Arab, M.A. Ultra High Strength Concrete Using Economical Materials. Int. J. Curr. Eng. Technol. 2013, 3, 393-402.

21. Yu, R.; Spiesz, P.; Brouwers, H.J.H. Mix design and properties assessment of Ultra-High Performance Fibre Reinforced Concrete (UHPFRC). Cem. Concr. Res. 2014, 56, 29-39. [CrossRef]

22. Radjy, F.; Richards, C.W. Effect of curing and heat treatment history on the dynamic mechanical response and the pore structure of hardened cement paste. Cem. Concr. Res. 1973, 3, 7-21. [CrossRef]

23. Mouret, M.; Bascoul, A.; Escadeillas, G. Strength impairment of concrete mixed in hot weather: Relation to porosity of bulk fresh concrete paste and maturity. Mag. Concr. Res. 2003, 55, 215-223. [CrossRef]

24. Verbeck, G.J. Structures and physical properties of cement paste. In Proceedings of the 5th International Congress on the Chemistry of Cement, Tokyo, Japan, 7-11 October 1968; Volume 3, pp. 1-37.

25. Ho, D.W.S.; Chua, C.W.; Tam, C.T. Steam-cured concrete incorporating mineral admixtures. Cem. Concr. Res. $2003,33,595-601$. [CrossRef]

26. Valikhani, A.; Jahromi, A.J.; Mantawy, I.M.; Azizinamini, A. Numerical modelling of concrete-to-UHPC bond strength. Materials 2020, 13, 1379. [CrossRef]

27. Shihada, S.; Arafa, M. Effects of silica fume, ultrafine and mixing sequences on properties of ultra high performance concrete. Asian J. Mater. Sci. 2010, 2, 137-146. [CrossRef]

28. Qadir, H.H.; Faraj, R.H.; Sherwani, A.F.H.; Mohammed, B.H.; Younis, K.H. Mechanical properties and fracture parameters of ultra high performance steel fiber reinforced concrete composites made with extremely low water per binder ratios. SN Appl. Sci. 2020, 2, 1594. [CrossRef]

29. Mohammed, B.H.; Sherwani, A.F.H.; Faraj, R.H.; Qadir, H.H.; Younis, K.H. Mechanical properties and ductility behavior of ultrahigh performance fiber reinforced concretes: Effect of low water-to-binder ratios and micro glass fibers. Ain Shams Eng. J. 2021. [CrossRef]

30. Gesoglu, M.; Güneyisi, E.; Muhyaddin, G.F.; Asaad, D.S. Strain hardening ultra-high performance fiber reinforced cementitious composites: Effect of fiber type and concentration. Compos. Part B Eng. 2016, 103, 74-83. [CrossRef]

31. Gesoglu, M.; Güneyisi, E.; Asaad, D.S.; Muhyaddin, G.F. Properties of low binder ultra-high performance cementitious composites: Comparison of nanosilica and microsilica. Constr. Build. Mater. 2016, 102, 706-713. [CrossRef]

32. Yazıcı, H.; Yardımcı, M.Y.; Aydın, S.; Karabulut, A.Ş. Mechanical properties of reactive powder concrete containing mineral admixtures under different curing regimes. Constr. Build. Mater. 2009, 23, 1223-1231. [CrossRef]

33. Foy, C.; Pigeon, M.; Banthia, N. Freeze-thaw durability and deicer salt scaling resistance of a 0,25 water-cement ratio concrete. Cem. Concr. Res. 1988, 18, 604-614. [CrossRef]

34. Nallathambi, P.; Karihaloo, B.L.; Heaton, B.S. Effect of specimen and crack sizes, water/cement ratio and coarse aggregate texture upon fracture toughness of concrete. Mag. Concr. Res. 1984, 36, 227-236. [CrossRef]

35. ASTM C494/C494M-13 Standard Specification for Chemical Admixtures for Concrete. In ASTM International; ASTM International: West Conshohocken, PA, USA, 2013; p. 10.

36. Corinaldesi, V.; Moriconi, G. Mechanical and thermal evaluation of Ultra High Performance Fiber Reinforced Concretes for engineering applications. Constr. Build. Mater. 2012, 26, 289-294. [CrossRef]

37. Yazici, H.; Yiğiter, H.; Karabulut, A.Ş.; Baradan, B. Utilization of fly ash and ground granulated blast furnace slag as an alternative silica source in reactive powder concrete. Fuel 2008, 87, 2401-2407. [CrossRef]

38. Yazici, H.; Yardimci, M.Y.; Yiğiter, H.; Aydin, S.; Türkel, S. Mechanical properties of reactive powder concrete containing high volumes of ground granulated blast furnace slag. Cem. Concr. Compos. 2010, 32, 639-648. [CrossRef] 
39. Aydin, S.; Yazici, H.; Yardimci, M.Y.; Yigiter, H. Effect of aggregate type on mechanical properties of reactive powder concrete. ACI Mater. J. 2010, 107, 441-449. [CrossRef]

40. ASTM C39/C39M-12 Standard Specification for Compressive Strength of Cylindrical Concrete Specimens; ASTM International: West Conshohocken, PA, USA, 2012; pp. 1-7.

41. ASTM C 496 Standard Test Method for Splitting Tensile Strength of Cylindrical Concrete Specimen; ASTM International: West Conshohocken, PA, USA, 2011; pp. 1-5.

42. ASTM C469/C469M-14 Standard Test Method for Static Modulus of Elasticity and Poisson's Ratio of Concrete in Compression; ASTM International: West Conshohocken, PA, USA, 2014.

43. Hillerborg, A.; Modéer, M.; Petersson, P.-E. Analysis of crack formation and crack growth in concrete by means of fracture mechanics and finite elements. Cem. Concr. Res. 1976, 6, 773-781. [CrossRef]

44. Rilem, D.R. Determination of the fracture energy of mortar and concrete by means of three-point bend tests on notched beams Mater. Struct. 1985, 18, 287-290. [CrossRef]

45. Akcay, B.; Agar-Ozbek, A.S.; Bayramov, F.; Atahan, H.N.; Sengul, C.; Tasdemir, M.A. Interpretation of aggregate volume fraction effects on fracture behavior of concrete. Constr. Build. Mater. 2012, 28, 437-443. [CrossRef]

46. Dhir, R.; Henderson, N. Specialist Techniques and Materials for Concrete Construction; Thomas Telford Publishing: London, UK, 1999; ISBN 9780727728258.

47. Hillerborg, A. The theoretical basis of a method to determine the fracture energy G F of concrete. Mater. Struct. 1985, 18, 291-296. [CrossRef]

48. Gesoğlu, M.; Özbay, E. Effects of mineral admixtures on fresh and hardened properties of self-compacting concretes: Binary, ternary and quaternary systems. Mater. Struct. 2007, 40, 923-937. [CrossRef]

49. Yu, R.; Spiesz, P.; Brouwers, H.J.H. Static properties and impact resistance of a green Ultra-High Performance Hybrid Fibre Reinforced Concrete (UHPHFRC): Experiments and modeling. Constr. Build. Mater. 2014, 68, 158-171. [CrossRef]

50. Park, J.S.; Kim, Y.J.; Cho, J.R.; Jeon, S.J. Early-age strength of ultra-high performance concrete in various curing conditions. Materials 2015, 8, 5537-5553. [CrossRef] [PubMed]

51. Gesoglu, M.; Güneyisi, E.; Nahhab, A.H.; Yazici, H. Properties of ultra-high performance fiber reinforced cementitious composites made with gypsum-contaminated aggregates and cured at normal and elevated temperatures. Constr. Build. Mater. 2015, 93, 427-438. [CrossRef]

52. Mukharjee, B.B.; Barai, S.V. Influence of Nano-Silica on the properties of recycled aggregate concrete. Constr. Build. Mater. 2014, 55, 29-37. [CrossRef]

53. Ahmed, H.U.; Faraj, R.H.; Hilal, N.; Mohammed, A.A.; Sherwani, A.F.H. Use of recycled fibers in concrete composites: A systematic comprehensive review. Compos. Part B Eng. 2021, 108769. [CrossRef]

54. Gencel, O.; Brostow, W.; Datashvili, T.; Thedford, M. Workability and Mechanical Performance of Steel Fiber-Reinforced Self-Compacting Concrete with Fly Ash. Compos. Interfaces 2011, 18, 169-184. [CrossRef]

55. Feldman, R.F.; Beaudoin, J.J. Microstructure and strength of hydrated cement. Cem. Concr. Res. 1976, 6, 389-400. [CrossRef]

56. Alaee, F.J. Retrofitting of Concrete Structures Using High Performance Fibre Reinforced Cementitious Composite (HPFRCC). Ph.D. Thesis, Cardiff University, Cardiff, UK, 2002.

57. Wu, Z.; Khayat, K.H.; Shi, C. How do fiber shape and matrix composition affect fiber pullout behavior and flexural properties of UHPC? Cem. Concr. Compos. 2018, 90, 193-201. [CrossRef]

58. Beygi, M.H.A.; Kazemi, M.T.; Nikbin, I.M.; Amiri, J.V. The effect of water to cement ratio on fracture parameters and brittleness of self-compacting concrete. Mater. Des. 2013, 50, 267-276. [CrossRef]

59. Zhang, J.; Leung, C.K.Y.; Xu, S. Evaluation of fracture parameters of concrete from bending test using inverse analysis approach. Mater. Struct. Constr. 2010, 43, 857-874. [CrossRef]

60. Petersson, P.E. Fracture energy of concrete: Practical performance and experimental results. Cem. Concr. Res. 1980, 10, 91-101. [CrossRef]

61. Faraj, R.H.; Sherwani, A.F.H.; Daraei, A. Mechanical, fracture and durability properties of self-compacting high strength concrete containing recycled polypropylene plastic particles. J. Build. Eng. 2019, 25, 100808. [CrossRef] 